\title{
Investigation and Analysis on DRS Condition of Agricultural University Libraries in China
}

\author{
Linlin Zhang \\ Heilongjiang Bayi Agricultural University Library, Heilongjiang Bayi Agricultural University, Daqing, China \\ Email: liblin@126.com
}

Received 23 November 2015; accepted 14 February 2016; published 17 February 2016

Copyright (C) 2016 by author and Scientific Research Publishing Inc. This work is licensed under the Creative Commons Attribution International License (CC BY). http://creativecommons.org/licenses/by/4.0/ c) (i) Open Access

\section{Abstract}

31 investigated higher agricultural college libraries all provide the reference consulting service. The service mode includes asynchronous reference consulting, synchronous reference consulting, synchronous and asynchronous reference consulting, joint reference consulting service and traditional reference consulting service. Service items include interlibrary borrowing and document delivery, reader training, special database, resource navigation and so on. But there are some problems to be solved.

\section{Keywords}

\section{Agricultural University Library, Digital Reference Consulting, Problems, Countermeasures}

\section{Introduction}

Extensive use of electronic information resources and extensive propagation of network information will make the library unavoidably encounter austere challenges. It is obvious that the traditional service mode of the libraries cannot fully satisfy the requirements of readers, so the library should explore the digital services and avoid edge effect in digital age by using the strength in self-resource. Now the digital libraries are emerging consecutively. Digital libraries can transfer the information resources to the reader's desktop via the network. Generally readers do not know how to effectively utilize these resources, so readers request the libraries to provide related fitting services. Digital reference consulting service (called as DRS) emerges [1]. It symbolizes that libraries are exploring their professional services by using the network platform. The digital reference consulting service becomes the new trend of the reference consulting service development of libraries under the network information environment. 
Digital libraries are the important reference information guarantee base for teaching and scientific research, which have plentiful opportunities in digital reference consulting services by depending on strengths in the hardware devices and talent of the universities. Although some well-known university libraries lead in China by referring to successful experiences in the digital reference consulting service and the gap with the foreign libraries reduces, the fact is not satisfactory. To improve comprehensive recognition on the digital reference consulting service of the university libraries, the author investigates the library DRS conditions of the agricultural universities in China in order to find the problems via the empirical research and decide purposeful countermeasures, which is practical for promoting research on the library DRS of agricultural universities.

\section{Survey Approaches and Methods}

The author visited CERNET, carried on the detailed investigation and research on the web pages of libraries of 31 ordinary higher agricultural colleges and universities in "Education Resources - China's University" Column, extracted related content of reference consulting service of libraries of 22 colleges and universities, including service form and service projects, and entered them into Excel and Word documents for detailed screening, classification, sorting, statistics and analysis.

\section{Network Investigation and Analysis of DRS Condition of Agricultural Universities in China}

Libraries provide DRS service later in China. Except a minority of well-known university libraries in China, which have stronger comprehensive strength and actual operation experiences, most university libraries have different problems in DRS service. The author investigates 31 agricultural university libraries in China via the network on 14 January 2015, including the state-affiliated key universities and general local agricultural universities. The invested universities basically cover most areas in China.

In 31 investigated agricultural university libraries, the homepages of 5 libraries fail to be linked. The homepages of 2 libraries include DRS services, namely $22 \%$ invested libraries have network problems and cannot be further investigated, namely $6 \%$ university libraries do not provide DRS service.

The investigation results indicate that although 22 agricultural university libraries implement different DRS, the DRS pattern is asynchronously interactive. Few DRS implements interactive DRS. No university implements the cooperative DRS. Specific research projects and survey result see Table 1. Survey results show, 32\% investigated libraries have no FAQ. 82\% libraries perform DRS via emails or form. $77 \%$ libraries perform DRS inside the libraries. 50\% libraries perform real-time reference consulting (referring to Table 2). It indicates that the digital reference consulting services implemented by the agricultural academies in China is under preliminary phase. DRS depth and extensiveness should be further explored. The service influence should be further improved, the service quality should be further perfected, and the recognition on DRS should be further strengthened.

\section{Problems in DRS of Agricultural University Libraries in China}

\subsection{Non-Perfect Service Function and Worse Whole Level}

The investigation indicates that the whole level of agricultural university libraries is low in DRS service. $60 \%$ investigated libraries perform DRS service, but the DRS service features obviously insufficient depth and extensiveness and is mainly implemented via E-mail, FAQ and Web form and its combined manner. It belongs to first-generation DRS service. The real-time DRS service indicates that the experts (or reference librarians) directly "face" users under virtual environment, namely answer the questions proposed by users, which is also called as the real-time interactive reference service (Interactive Reference Services, IRS). Now the software such as chartroom or video conference is mainly used for implementation [2]. Table 1 indicates that the agricultural university libraries are based on the digital reference service using the real-time interactive technologies. The DRS features slow development and popularization speed due to technology reasons. Such worse conditions are caused by many factors, including insufficient human resources, insufficient resources, lack of digital reference consulting service experiences and adaptation software, no network or insufficient network service and no attention from leaders, so the DRS of the university libraries should be further improved and perfected. 
Table 1. 22 agricultural university libraries reference form.

\begin{tabular}{|c|c|c|c|c|c|c|c|c|c|}
\hline Library Name & FAQ & E-Mail & $\begin{array}{l}\text { Forms } \\
\text { Advisory }\end{array}$ & $\begin{array}{l}\text { Visitors } \\
\text { Book }\end{array}$ & Blog & $\begin{array}{l}\text { QQ Online } \\
\text { Consultation }\end{array}$ & $\begin{array}{l}\text { Online Service } \\
\text { Timely Answers }\end{array}$ & $\begin{array}{l}\text { Mobile } \\
\text { Library }\end{array}$ & $\begin{array}{l}\text { Cooperative } \\
\text { Reference }\end{array}$ \\
\hline $\begin{array}{l}\text { Beijing Forestry } \\
\text { University }\end{array}$ & Y & & Y & Y & & $\mathrm{Y}$ & & & \\
\hline $\begin{array}{c}\text { China Agricultural } \\
\text { University }\end{array}$ & Y & $\mathrm{Y}$ & & Y & & Y & Y & & Y \\
\hline $\begin{array}{l}\text { Agricultural University } \\
\text { of Hebei Province }\end{array}$ & & Y & & & & & & & Y \\
\hline $\begin{array}{l}\text { Shanxi } \\
\text { Agricultural University }\end{array}$ & Y & & Y & & & Y & Y & & \\
\hline $\begin{array}{c}\text { Inner Mongolia } \\
\text { Agricultural University }\end{array}$ & & Y & Y & & & & Y & & \\
\hline $\begin{array}{c}\text { Shenyang Agricultural } \\
\text { University }\end{array}$ & & Y & & & & & & & \\
\hline $\begin{array}{l}\text { Jilin Agricultural } \\
\text { University }\end{array}$ & Y & $\mathrm{Y}$ & & & & Y & & $\mathrm{Y}$ & Y \\
\hline $\begin{array}{c}\text { Northeast } \\
\text { Agricultural University }\end{array}$ & & Y & & $\mathrm{Y}$ & & & & & Y \\
\hline $\begin{array}{c}\text { Northeast Forestry } \\
\text { University }\end{array}$ & & $\mathrm{Y}$ & & & & & & $\mathrm{Y}$ & Y \\
\hline $\begin{array}{c}\text { Nanjing } \\
\text { Agricultural University }\end{array}$ & Y & $\mathrm{Y}$ & & $\mathrm{Y}$ & & Y & & $\mathrm{Y}$ & \\
\hline $\begin{array}{l}\text { Nanjing Forestry } \\
\text { University }\end{array}$ & $\mathrm{Y}$ & & & Y & & Y & & & \\
\hline $\begin{array}{l}\text { Anhui Agricultural } \\
\text { University }\end{array}$ & $\mathrm{Y}$ & & & Y & & & & $\mathrm{Y}$ & \\
\hline $\begin{array}{c}\text { Shandong } \\
\text { Agricultural University }\end{array}$ & Y & $\mathrm{Y}$ & & & & $\mathrm{Y}$ & & & Y \\
\hline $\begin{array}{l}\text { Zhejiang A \& F } \\
\text { University }\end{array}$ & & $\mathrm{Y}$ & & $\mathrm{Y}$ & & $\mathrm{Y}$ & & & \\
\hline $\begin{array}{c}\text { Jiangxi } \\
\text { Agricultural University }\end{array}$ & Y & $\mathrm{Y}$ & & & & Y & & & Y \\
\hline $\begin{array}{l}\text { Fujian Agriculture and } \\
\text { Forestry University }\end{array}$ & Y & Y & & $\mathrm{Y}$ & & & Y & & \\
\hline $\begin{array}{c}\text { Huazhong } \\
\text { Agricultural University }\end{array}$ & Y & $\mathrm{Y}$ & & & & & & & Y \\
\hline $\begin{array}{c}\text { Hunan } \\
\text { Agricultural University }\end{array}$ & Y & Y & Y & & & $\mathrm{Y}$ & & & Y \\
\hline $\begin{array}{c}\text { Henan } \\
\text { Agricultural University }\end{array}$ & Y & Y & Y & $\mathrm{Y}$ & Y & & $\mathrm{Y}$ & & $\mathrm{Y}$ \\
\hline $\begin{array}{c}\text { South China } \\
\text { Agricultural University }\end{array}$ & Y & Y & Y & & & Y & Y & & $\mathrm{Y}$ \\
\hline $\begin{array}{c}\text { Sichuan Agricultural } \\
\text { University }\end{array}$ & & Y & & Y & & & & & \\
\hline $\begin{array}{l}\text { Northwest A \& F } \\
\text { University }\end{array}$ & Y & Y & Y & & & & & Y & \\
\hline Total & 15 & 18 & 7 & 9 & 1 & 11 & 6 & 5 & 11 \\
\hline
\end{tabular}

Table 2. Implementation conditions of reference consulting of 22 agricultural universities.

\begin{tabular}{ccc}
\hline Reference Consulting Form & University Quantity & Percent \\
\hline FAQ service & 15 & 68 \\
E-mail service & 18 & 82 \\
Consulting inside library & 17 & 77 \\
Real-time reference on cooperative reference consulting & 11 & 50 \\
User education & 11 & 50 \\
\hline
\end{tabular}




\subsection{DRS Position Is Not Highlighted on the Library Homepage and the Pattern Is Not Standardized}

The investigation indicates that the percent of the digital reference consulting service is insufficient in the whole work of libraries, e.g. the identifier and names of the DRS are chaotic. As a symbolic service, it should be located at a highlighted position on the library homepage and can show its importance. The investigation results indicate that some libraries locate the DRS on the L2 link. Readers cannot easily find this link to use these services. Some universities mix the reference consulting with the reader guide, so readers cannot easily find it. Generally the DRS is called as the consulting expert, virtual reference consulting, electronic reference consulting, remote reference consulting, network reference consulting, but some libraries name it as the "online word leaving" and "word leaving plate". Although the service pattern of the digital reference consulting includes the word leaving board as the asynchronous interaction manner, the service names should be standardized to correctly guide the users to use the service. The above problems are generated due to insufficient recognition on importance of the digital reference consulting in the digital reference information service.

\subsection{Lack of Cooperative DRS}

The reference consulting services of the agricultural university libraries are performed separately. No cooperative reference consulting service is available, so it is unfavorable to the emerging DRS service and the research foundation for cooperation is not solid in DRS. It will affect DRS much. On the contrary, it will restrict evolvement of DRS and form malicious circulation. The DRS quality cannot be ensured. The DRS of libraries are under the preliminary phase. Quality of persons and owned resources are not perfect. All libraries should be united to carry out the cooperative reference consulting. All libraries should exert their strengths, offset weaknesses, and provide higher quality.

\subsection{Lack of Professional DRS Talents}

The consulting experts control quality of the digital reference consulting. Their information quality and occupational morality will directly affect quality of the information service and DRS. The consulting experts not only have better information quality, rich knowledge, higher foreign language level, and certain professional knowledge, collect, arrange, analyze and use information via different means, but also should have better occupational morality and dedication spirits and can carefully deal with and handle each consulting requests of users. Now most DRS consultors are acted by librarians of a department (e.g. information department) of the libraries in China. Most consultors are not from the book intelligence specialty, so they are lack of the knowledge extensiveness and information integration and application capability.

As the "processor of reference consulting", the Samuel-Greekn, director of the Wooster public library in America, highlighted "importance of the individual help for readers seeking information" and pointed out function information, guidance and reader education of the reference consulting [3]. It launches theory of the reference consulting service. Now some agricultural university libraries cannot better explain three functions of the reference consulting in the digital reference consulting service. No library can perform the reference consulting service completely in three fields, so the service quality should be further improved and the meaning should be further mined. The service means should be further perfected.

\section{DRS Development Countermeasures and Recommendations of Agricultural University Library}

\subsection{Strengthen Advertisement and Improve DRS Idea of Users}

As the new form of the information service in the digital age, DRS changes the service idea, service pattern, and service effect of the reference consulting as a new service mode. Different agricultural university libraries pay different attention. The author thinks that the link of the DRS service should be located at the highlighted position on the library homepage. The readers should be reminded at proper time to cultivate DRS service consciousness of the users and facilitate use [4]. The advertisement should be strengthened to enhance the information quality of the users and make them truly understand potential value. The user requirements are the main force to drive digital reference consulting service. 


\subsection{Strengthen Standardization of DRS}

DRS requires cooperation from different parties, especially cooperative DRS implementation, so the DRS standardization is very important and urgent. DRS standards involve many aspects, including technology standard, service standard, information exchange format standard, information sharing standard, metadata standard and quality control standard. If no standard is available, DRS implementation only keeps at a lower level, will not reach true purpose of the DRS, cannot meet user requirements, and further affect DRS development. How to refer to DRS experiences of other libraries and enrich our standardization issues should be emphasized by the agricultural university library.

\subsection{Carry out Cooperation by Participating in and Simulating Domestic Well-Known Cooperative DRS Projects}

Now the domestic well-known cooperative reference consulting service in China includes the state library information consulting and cooperation network and united network knowledge navigation website. We can invite the agricultural university library to join in it, so it can improve quality of the agricultural university DRS and further drive the cooperative DRS of the agricultural university libraries in China. This means we need not start with beginning, so it can save investment of some manpower and finance in establishment period of cooperative DRS and increase implementation possibility of cooperative DRS in an intangible manner. For issues such as separate development and no uniform plan, the state large-scale library and related governmental departments should have a whole plan for system construction, integrate resources of different organizations, coordinate relation among members, break current separate layout, establish uniform reference consulting platform, and provide comprehensive high-quality service, especially cooperative reference consulting and distributed reference consulting not only integrates limited resources of libraries and meets different user requirements as much as possible, but also solves the lack of consulting experts, so it should be encouraged.

\subsection{Found "Virtual Team" to Improve DRS Quality}

The "virtual team" is different from traditional entity team. Members do not depend on tangible office site. They will work in a virtual space and mainly depend on modern communication and information technologies to realize the remote communication and coordination [5]. The virtual team mainly engages the high-knowledge work. Members should be composed of high-level professional experts, who can cross geographical position specialty and function department. They should contact and exchange with each via advanced communication technologies such as electronic means, including email, network chat, telephone, and video conference. Their work and service is mainly implemented via a remote manner. The members of the virtual team will cooperate with each other to solve complicated problems to meet the requirements of the users and organizations via their knowledge.

Now DRS has acted as the main role in the library service. Its service quality will directly affect whole image of the library. If the service quality is not guaranteed and no corresponding control measures of the consulting quality, DRS cannot be recognized and extensively utilized by extensive users, so we should strengthen deep research on the DRS. By combining the actual DRS experiences of the agricultural university library, we can launch personalized, proactive, multi-level and multi-view whole-process digital reference consulting service, and provide beneficial help for the university libraries to carry out DRS.

\section{Fund}

Heilongjiang Philosophy and Social Science Plan research project "information service system building of university libraries in big data age" (project number: 14E045).

Heilongjiang Art and Science Plan co-building project "research on library service innovation development in new media age" (project number: 2014D014).

\section{References}

[1] Liu, L. and Li, X.J. (2012) University Library Marketing and Reference with Network Embedded Community: Exploration of Library Service Based on Sina Microblogging. Library Journal, No. 7. 
[2] Shang, F.-Y. (2015) Research on the Mode of Digital Reference Services Based on WeChat Public Plat Form. Journal of Academic Library and Information Science, No. 4.

[3] Yang, F. (2014) Exploring New Field of Reference Consulting Service in the Big Data Age. Journal of Library and Information Sciences in Agriculture, No. 12.

[4] Yuan, H.-J. (2015) Research on the Ecological Mechanism for Knowledge Transfer in Collaborative Digital Reference Service. Information Science, No. 1.

[5] Liu, H.H. (2008) DRS Development Trend Analysis of Domestic Libraries. Journal of Xiangtan Normal College, No. 7, 55-58. 